\title{
Lactose in blood plasma and the ability of dairy cows to tolerate once-daily milking in terms of milk loss and milk recovery
}

\author{
J. Guinard-Flament, ${ }^{*}{ }^{1}$ Y. Gallard, $\neq$ and H. Larroque \\ ${ }^{*}$ Agrocampus Ouest, UMR1080 Production du Lait, F-35042 Rennes cedex, France \\ †INRA, UMR1080 Production du Lait, F-35590 Saint-Gilles, France \\ fINRA, UE0326, Domaine expérimental du Pin-au-Haras, F-61310 Exmes, France \\ §INRA, UR0631, Station d'Amélioration Génétique des Animaux, F-31326 Castanet-Tolosan cedex, France
}

\begin{abstract}
This experiment described the variability among cows with the aim of studying the ability of dairy cows to tolerate once-daily milking (ODM) in terms of milk losses and milk recoveries observed when cows are switched from twice- to once-daily milking and then back to twice-daily milking (TDM). It also aimed to investigate whether or not lactose in blood plasma, which indicates the mammary epithelium permeability, is correlated with milk losses and recoveries and, consequently, a potential candidate assessor of dairy cow tolerance to ODM. The study used 86 crossbred dairy cows (Holstein $\times$ Normande) split into 5 groups over 2 yr. The trial consisted of 3 successive periods: a 1-wk control period of TDM, then 3 wk of ODM, followed by 2 wk of TDM. Blood samples were collected 1 to $1.5 \mathrm{~h}$ before the morning milking and 5 to $6 \mathrm{~h}$ after milking on $\mathrm{d}-3,0,1,3,7,21,23$, and 28 , where $\mathrm{d} 0$ is the last $\mathrm{d}$ of the control period. Milk losses measured as kilograms per day were higher in cows with highest control-period milk yields $(\mathrm{r}=-0.66)$. When expressed in relative terms (\%), milk losses were weakly correlated with the control-period milk yield $(\mathrm{r}=-0.22)$. When switched back to TDM, cows recovered only $47 \%$ of the milk lost. Milk recovery $(\mathrm{kg} / \mathrm{d})$ was weakly correlated with control milk yield $(\mathrm{r}=0.34)$ and not correlated with ODM milk yield. Milk recovery was correlated with milk yield losses: the higher the milk yield losses $(\mathrm{kg} / \mathrm{d}$ or \%), the higher the milk recovery $(\mathrm{kg} / \mathrm{d} ; \mathrm{r}=-0.59$ and -0.52 , respectively). Rate of milk recovery expressed as the quantity of milk recovered per kilogram of milk lost, was not correlated with milk loss expressed as a percentage. This means that to be considered well-adapted to ODM scheduling, a cow must be well adapted to milk loss, and be well adapted to milk recovery. Blood plasma lactose concentration ( $\log _{10}$-transformed data) was not correlated with milk production levels in either
\end{abstract}

Received December 10, 2010.

Accepted March 7, 2011.

${ }^{1}$ Corresponding author: Jocelyne.Flament@agrocampus-ouest.fr control, ODM, or back-to-TDM periods. It was poorly correlated with milk loss but was positively correlated with milk recovery $(\mathrm{kg} / \mathrm{d})$ and rate of milk recovery. We conclude that blood plasma lactose needs to be coupled with other indicators for evaluating dairy cow tolerance to ODM.

Key words: once-daily milking, milk loss, milk recovery, blood plasma lactose

\section{INTRODUCTION}

Once-daily milking (ODM) can be useful to dairy farms as it can decrease workload over a short or long period or even across an entire lactation cycle. However, switching dairy cows from twice- to once-a-day milking induces high milk yield losses that may or may not be associated with residual effects when switching back to twice-daily milking (TDM). The average drop in milk yield is about 20 to $30 \%$ during the declining phase of lactation, and the residual negative effect ranges from 2.4 to $8 \%$ after 3 wk of ODM (Rémond and Pomiès, 2005). However, the literature reports marked among-cow variability in milk responses (Holmes et al., 1992; Rémond and Pomiès, 2005; Hickson et al., 2006). Holmes et al. (1992) reported losses below $10 \%$ and approximating $50 \%$ when comparing twin cows milked once- or twice-daily. Such between-cow variations emphasize the challenge to identify and select cows able to handle the negative effects of ODM on milk production. This would contribute to increased labor productivity on farms (Davis, 2005). By extension, an effective method is needed for identifying cows well adapted (i.e., with minor loss in milk yield and minimized residual effects on milk).

Previous attempts have been made in New Zealand to identify predictive factors of cow tolerance to ODM (Carruthers et al., 1993; Davis et al., 1998a). These studies focused on production losses rather than milk recovery; dairy farms in New Zealand mainly use ODM during late or whole-cycle lactation and do not need a return to TDM. This contrasts with France, where farmers could be interested in implementing ODM 
Table 1. Number of Holstein $\times$ Normande cows, stage of lactation, and age at calving (mean \pm standard deviation) per group

\begin{tabular}{lccc}
\hline Group & $\begin{array}{c}\text { Cows, } \\
\mathrm{n}\end{array}$ & $\begin{array}{c}\text { Stage of } \\
\text { lactation, } \mathrm{d}\end{array}$ & $\begin{array}{c}\text { Age at } \\
\text { calving, mo }\end{array}$ \\
\hline 1 & 24 & $82 \pm 8.9$ & $41.1 \pm 4.54$ \\
2 & 26 & $82 \pm 11.7$ & $42.5 \pm 5.46$ \\
3 & 7 & $81 \pm 3.0$ & $42.1 \pm 4.38$ \\
4 & 20 & $79 \pm 5.0$ & $42.7 \pm 4.98$ \\
5 & 20 & $73 \pm 28.0$ & $45.4 \pm 4.67$ \\
\hline
\end{tabular}

over periods of a few days, several months, or over the whole lactation cycle (Rémond and Pomiès, 2005). The methods used were based on determining the partitioning of milk accumulation in the udder by estimating either the amount of residual milk (Carruthers et al., 1993) or size of cisternal and alveolar compartments (Davis et al., 1998a). Results showed that cows that store a larger proportion of their milk production in the cisternal compartment exhibit a lower decrease in milk yield when milked once daily (Davis et al., 1998a). However, these methods involve milking the cows twice and using oxytocin and adrenaline injections, which is problematic on a large scale in commercial farms.

Lactose in blood plasma could be a good alternative candidate for estimating a cow's ability to respond better to the negative effects of ODM. Indeed, impaired milk secretion when dairy cows are milked once per day is associated with an increase in permeability of the mammary epithelium, resulting in an increase in lactose concentration in blood plasma (Stelwagen et al., 1994, 1997). Lactose is produced solely by the mammary gland (Kuhn and Linzell, 1970), and according to Stelwagen et al. (1997), lactose in blood plasma is a reliable indicator for indirect in vivo assessment of tight junction integrity (i.e., the permeability of the mammary epithelium). Tight junctions are the extracellular structures between adjacent epithelial cells that act as barriers, preventing milk components from moving into the interstitial space, and vice versa. Lactose concentration begins to increase rapidly after $17 \mathrm{~h}$ of milk accumulation during the first $24 \mathrm{~h}$ of ODM in dairy cows (Stelwagen et al., 1997, 1998). After 6 d of ODM, greater plasma lactose concentrations are also observed because of both higher basal concentrations and an increase in concentrations occurring $16 \mathrm{~h}$ after milking (Delamaire and Guinard-Flament, 2005, 2006).

As losses in mammary epithelium integrity and milk yield occur concurrently in response to the switch from TDM to ODM, changes in milk yield could be related to a proportional disorganization of the mammary epithelium or inability of the mammary gland to restore epithelial integrity. As a result, lactose variations in blood plasma could be correlated with milk responses, which would make lactose an easily-measurable indicator of a cow's ability to tolerate ODM. Therefore, the present study was designed to describe the relationships between milk yield loss and milk recovery and determine whether individual milk loss and recovery, and plasma lactose concentrations are correlated in dairy cows switched back to TDM after a 3 -wk switch to ODM.

\section{MATERIALS AND METHODS}

This study used 97 Holstein $\times$ Normande crossbred dairy cows from the INRA Domaine expérimental du Pin experimental farm (authorization number: B 61157-001) split into 5 groups over 2 consecutive years (i.e., 24 and 26 dairy cows during the first year and 7 , 20 , and 20 dairy cows during the second year). All cows were in second lactation and of similar age at calving and lactation stage at the start of the experiment (see Table 1 for group-by-group details). The cows were kept indoors in deep litter housing with once-a-day mulching, and an average per-cow surface area of $7 \mathrm{~m}^{2}$. The housing was mucked out before the start of the experiment.

The experiment consisted of 3 successive periods: (1) 1 control wk where cows were milked twice daily (TDM1), (2) 3 wk of ODM to characterize milk yield losses, and (3) 2 wk of TDM (TDM2) to examine milk recovery. Cows were normally milked at 0630 and 1700 $\mathrm{h}$ during TDM and at $0800 \mathrm{~h}$ during ODM.

All cows were fed once daily at $0800 \mathrm{~h}$. They were offered the same diet throughout the experiment (including energy concentrate) to avoid any feeding effect on milk yield. Diet was formulated to meet the requirements of TDM cows (Institut National de la Recherche Agronomique, 1989) and consisted of grass silage (4 kg of $\mathrm{DM} / \mathrm{d})$, beet pulp (1 $\mathrm{kg}$ of $\mathrm{DM} / \mathrm{d})$, soybean meal (2 $\mathrm{kg}$ of $\mathrm{DM} / \mathrm{d})$, and corn silage offered ad libitum. Cows received $1 \mathrm{~kg}$ of energy concentrate $(2.13 \mathrm{Mcal}$ of $\mathrm{NE}_{\mathrm{L}}$ and $136 \mathrm{~g}$ of true protein, truly digestible in the small intestine $/ \mathrm{kg}$ of DM) for each daily $2.5 \mathrm{~kg}$ of milk produced above $21 \mathrm{~kg}$ of milk yield/d.

Milk yield was recorded every day and milk samples were collected $4 \mathrm{~d} /$ wk (from Monday to Thursday) throughout the experiment, and on blood sampling days. Milk analyses were performed at the Normandy Interprofessional Milk Analysis Laboratory (LILANO, Saint-Lô, France). Milk fat, protein, and lactose contents were determined by mid-infrared spectrometry (MilkoScan FT6000, Foss, Hillerød, Denmark) and SCC by a Fossomatic cell counter (Foss, Hillerød, Denmark).

Tail blood samples were collected using 5 -mL heparinized tubes (VT-050SHL, Venoject, Terumo Europe, Leuven, Belgium) 1 to $1.5 \mathrm{~h}$ before and 5 to $6 \mathrm{~h}$ after 
morning milking on $\mathrm{d}-3,0,1,3,7,21,23$, and 28 of the experiment (where $\mathrm{d} 0$ is the first $\mathrm{d}$ of ODM). Blood was centrifuged at $2,264 \times g$ for $15 \mathrm{~min}$, and the plasma was removed and stored at $-20^{\circ} \mathrm{C}$ until analysis. Plasma lactose concentration was assayed using a colorimetric enzymatic reaction (kit for lactose/Dgalactose, Scil Diagnostics GmbH, Meylan, France) with a multiparameter analyzer (KONE Instruments Corporation, Espoo, Finland).

Data on 11 cows were removed from the data set due to mastitis or inconsistent milk data. All statistical analyses on the data set for the 86 remaining cows were performed using SAS software (SAS Institute Inc., Cary, NC). The statistical significance threshold was set at $P<0.05$. Milk data and control plasma lactose concentration showed no significant within-period variation, they were averaged per period. Milk yield loss expressed in kilograms per day or percentage is the difference between ODM and TDM1 milk yields divided or not by TDM1 milk yield. Milk yield recovery $(\mathrm{kg} / \mathrm{d})$ is the difference between TDM2 and ODM milk yields. Milk recovery rate is the absolute value of the ratio between milk recovery $(\mathrm{kg} / \mathrm{d})$ and milk loss $(\mathrm{kg} / \mathrm{d})$. The residual effect of ODM expressed in kilograms per day or percentage is the difference between TDM1 and TDM2 milk yields divided or not by TDM1 milk yield. The normality of data was checked using the ShapiroWilk test of the SAS-package univariate procedure. The plasma lactose data set was transformed using a logarithmic scale. Somatic cell counts were transformed into SCS using the internationally accepted formula $\mathrm{SCS}=\log _{2}(\mathrm{SCC} / 100,000)+3$, where SCC is in units of 1,000 cells $/ \mathrm{mL}$.

The effects of the switches to ODM and back to TDM on milk yield and milk composition were analyzed using the MIXED procedure of the SAS package version 8 , according to the statistical model:

$$
\begin{aligned}
\mathrm{Y}_{\mathrm{ijk}}= & \mu+\operatorname{group}_{\mathrm{i}}+\operatorname{period}_{\mathrm{j}}+\operatorname{group}_{\mathrm{i}} \\
& \times \operatorname{period}_{\mathrm{j}}+\operatorname{cow}_{\mathrm{k}}+\varepsilon_{\mathrm{ijk}}
\end{aligned}
$$

where $\mu$ is the mean and $Y_{i j k}$ is the dependent variable on the fixed effects of group i (1 to 5 ) during period $\mathrm{j}$ (TDM1, ODM, TDM2) and their interaction, and the random effect of the cow $\mathrm{k}$, and $\varepsilon_{\mathrm{ijk}}$ is the residual error associated with each ijk observation.

\section{RESULTS AND DISCUSSION}

The 86 Holstein $\times$ Normande cows used in this trial were all in second lactation, and all at similar age at calving and stage of lactation (mean $=42.5$ mo and $79 \mathrm{~d}$ with $\mathrm{SD}=5.14 \mathrm{mo}$ and $15.6 \mathrm{~d}$, respectively).
The milk data nevertheless showed extensive amongcow variations (Table 2). During the control period (TDM1), milk yield and milk fat content showed almost $100 \%$ between-cow variability $(\mathrm{CV}=15.4$ and $14.5 \%$, respectively), whereas milk protein and lactose content showed lower between-cow variations $(\mathrm{CV}=$ 8 and $3 \%$, respectively). This individual variability remained steady throughout the 3 periods, despite the $\mathrm{TDM} \rightarrow \mathrm{ODM} \rightarrow \mathrm{TDM}$ switches (Table 2). The coefficients of variation in milk yield and composition were stable across the 3 periods. This variability underscores the utility of these data for studying the ability of dairy cows to better adapt to the negative effects of ODM on milk yield. The use of crossbred cows (F2 generation, Holstein $\times$ Normande; Larroque et al., 2002) explains the large range of variation in milk production and composition. Environmental factors had moderate effects because of the controlled environment. For instance, animal diet had only limited effects, as feeding strategy remained unchanged between groups, despite variations in feedstuff quality.

\section{Relationships Between Milk Responses to ODM and Return to TDM}

The ability of cows to tolerate ODM involves examining milk yield loss and residual effects when switching back to TDM. In most published papers, the effects of switching cows from TDM to ODM have been described in comparison to the reverse switch (switching cows back from ODM to TDM), as the aim has generally been to develop strategies to minimize milk yield loss. The residual effects, when described, only concern average variations (not individual variations) according to stage of lactation and ODM period length (Rémond and Pomiès, 2005). Thus, one of the objectives of this study was to describe individual relationships between loss and recovery in milk yield.

Averaged Variations. The variations observed here were in agreement with previous reports (Davis et al., 1999; Rémond and Pomiès, 2005). In response to ODM, milk yield and milk lactose content decreased by 8.8 $\mathrm{kg} / \mathrm{d}$ and $2.2 \mathrm{~g} / \mathrm{kg}$, respectively, and milk protein and milk fat contents, and the SCS increased 0.5 and $3.3 \mathrm{~g} /$ $\mathrm{kg}$, and 0.5 units, respectively (Table 3 ). When cows were switched back to TDM after 3 wk of ODM, milk yield, and milk lactose and milk protein contents increased $4.1 \mathrm{~kg} / \mathrm{d}, 1.4$, and $1 \mathrm{~g} / \mathrm{kg}$, respectively, whereas milk fat content decreased by $2.6 \mathrm{~g} / \mathrm{kg}$. Somatic cell score remained higher than in the TDM1 period. The animals recovered only $47 \%$ of the milk they lost. Milk yield, when switched back to TDM, was $15 \%$ lower compared with the TDM1 period. Considering a lactation persistency of $98 \% / \mathrm{wk}$, this decrease was 5 to $7 \%$, 
Table 2. Milk yield and composition of Holstein $\times$ Normande cows during the twice-daily-milking control period (TDM1), the once-daily-milking period (ODM), and the back-to-twice-daily-milking period (TDM2; $\mathrm{n}$ $=86)$

\begin{tabular}{|c|c|c|c|c|}
\hline Item & Mean & Minimum & Maximum & $\mathrm{SD}$ \\
\hline \multicolumn{5}{|l|}{ TDM1 } \\
\hline Milk yield, kg/d & 31.0 & 21.2 & 40.3 & 4.78 \\
\hline Milk lactose, $\mathrm{g} / \mathrm{kg}$ & 49.5 & 45.1 & 52.4 & 1.68 \\
\hline Milk true protein, $\mathrm{g} / \mathrm{kg}$ & 31.5 & 26.9 & 38.3 & 2.62 \\
\hline Milk fat, $\mathrm{g} / \mathrm{kg}$ & 42.8 & 29.9 & 59.0 & 6.21 \\
\hline Milk SCS & 2.0 & -0.6 & 6.5 & 1.67 \\
\hline \multicolumn{5}{|l|}{ ODM } \\
\hline Milk yield, kg/d & 22.1 & 13.1 & 31.4 & 3.62 \\
\hline Milk lactose, $\mathrm{g} / \mathrm{kg}$ & 47.2 & 43.4 & 50.8 & 1.72 \\
\hline Milk true protein, $\mathrm{g} / \mathrm{kg}$ & 31.9 & 26.6 & 38.2 & 2.42 \\
\hline Milk fat, $\mathrm{g} / \mathrm{kg}$ & 46.0 & 32.6 & 70.8 & 7.01 \\
\hline Milk SCS & 2.5 & 0.2 & 6.1 & 1.21 \\
\hline \multicolumn{5}{|l|}{ TDM2 } \\
\hline Milk yield, kg/d & 26.4 & 17.8 & 35.2 & 4.38 \\
\hline Milk lactose, $\mathrm{g} / \mathrm{kg}$ & 48.7 & 42.3 & 51.7 & 1.71 \\
\hline Milk true protein, $\mathrm{g} / \mathrm{kg}$ & 32.9 & 27.4 & 39.0 & 2.46 \\
\hline Milk fat, $\mathrm{g} / \mathrm{kg}$ & 43.4 & 32.1 & 66.3 & 6.66 \\
\hline Milk SCS & 2.5 & 0.2 & 5.2 & 1.21 \\
\hline
\end{tabular}

which is consistent with the 5 to $8 \%$ residual milk loss observed when ODM is carried out over 3 wk (Rémond and Pomiès, 2005).

Individual Variations in Milk Yield. In the present study, and as reported by Rémond and Pomiès (2005), high milk production from cows in the control period was associated with higher milk yield loss $(\mathrm{kg} / \mathrm{d})$ after the switch to ODM $(\mathrm{r}=-0.66$; Table 4$)$. When expressed in relative terms (\%), these losses were slightly correlated with the initial production level (r $=-0.22$ ). Conversely, Rémond and Pomiès (2005) observed no significant correlation between loss (\%) and initial production level $(\mathrm{r}=-0.01)$. This discrepancy could arise from the greater heterogeneity of the 237 individual data sets compiled by Rémond and Pomiès on breed, parity, lactation stage, and age at calving.

When the cows were switched back to TDM after 3 wk of ODM, milk yield increased. Milk recovery $(\mathrm{kg} / \mathrm{d})$ was positively but weakly correlated with initial production level $(\mathrm{r}=0.34)$ and not correlated with ODM milk yield (Table 4). Milk recovery was correlated with milk yield losses: the higher the loss in milk yield $(\mathrm{kg} / \mathrm{d}$ or \%), the higher the milk recovery $(\mathrm{kg} / \mathrm{d}$; $\mathrm{r}=-0.59$ and -0.52 , respectively). However, Figure 1 shows broad among-cow variability. The cows showing the highest milk yield losses were penalized by being unable to recover their initial milk yield. Indeed, among the cows that lost 8 to $14 \mathrm{~kg} / \mathrm{d}$ of milk, none recovered their initial milk yield level, in contrast to the cows that lost 4 to $6 \mathrm{~kg} / \mathrm{d}$ of milk. Another way to describe milk recovery is to estimate milk recovery rate, which is the daily quantity of milk recovered per kilogram of daily milk lost. Here, milk recovery rate did not correlate with initial or ODM production levels, or with milk yield losses expressed in either kilogram per day or percentage (Table 4). Milk recovery rate was independent of cow production levels before and during ODM, and was also independent of quantity of milk lost.

Focusing on a cow's ability to tolerate ODM schedules, a well-adapted cow can be depicted as a cow showing minor milk losses when switched to ODM and strong recovery when switched back to TDM. The most valuable criteria for describing good adaptability are respectively, milk loss as a percentage and milk recovery rate. Indeed, milk loss has to be low regardless of initial milk yield, and milk recovery has to be strong enough to at least recover all of the lost milk. We found that these 2 criteria are not correlated, meaning that a cow's ability to tolerate ODM practice is the sum of 2 independent abilities: its ability to show relatively little milk loss and its ability to demonstrate a strong recovery rate. Hence, to be considered well adapted to an ODM schedule, a cow has to cumulate these 2 abilities, which means dairy farmers have to identify or even select these 2 aptitudes. Genetics may influence both aptitudes but not necessarily in the same manner. To

Table 3. Effect of switching Holstein $\times$ Normande cows from twicedaily milking (TDM1) to once-daily milking (ODM) and back to twice-daily milking (TDM2) on milk yield and composition $(\mathrm{n}=86)^{1}$

\begin{tabular}{lcccc}
\hline Item & TDM1 & ODM & TDM2 & SEM \\
\hline Milk yield, $\mathrm{kg} / \mathrm{d}$ & $30.7^{\mathrm{a}}$ & $21.9^{\mathrm{c}}$ & $26.0^{\mathrm{b}}$ & 0.50 \\
Milk lactose, g/kg & $49.4^{\mathrm{a}}$ & $47.2^{\mathrm{c}}$ & $48.6^{\mathrm{b}}$ & 0.20 \\
Milk true protein, g/kg & $31.5^{\mathrm{c}}$ & $32.0^{\mathrm{b}}$ & $33.0^{\mathrm{a}}$ & 0.30 \\
Milk fat, g/kg & $42.8^{\mathrm{b}}$ & $46.1^{\mathrm{a}}$ & $43.5^{\mathrm{b}}$ & 0.79 \\
Milk SCS & $2.1^{\mathrm{b}}$ & $2.6^{\mathrm{a}}$ & $2.7^{\mathrm{a}}$ & 0.17 \\
\hline
\end{tabular}

${ }^{\mathrm{a}-\mathrm{C}}$ Means within a row with different superscripts differ at $P<0.05$.

${ }^{1}$ Least squares means with standard error of the mean. 


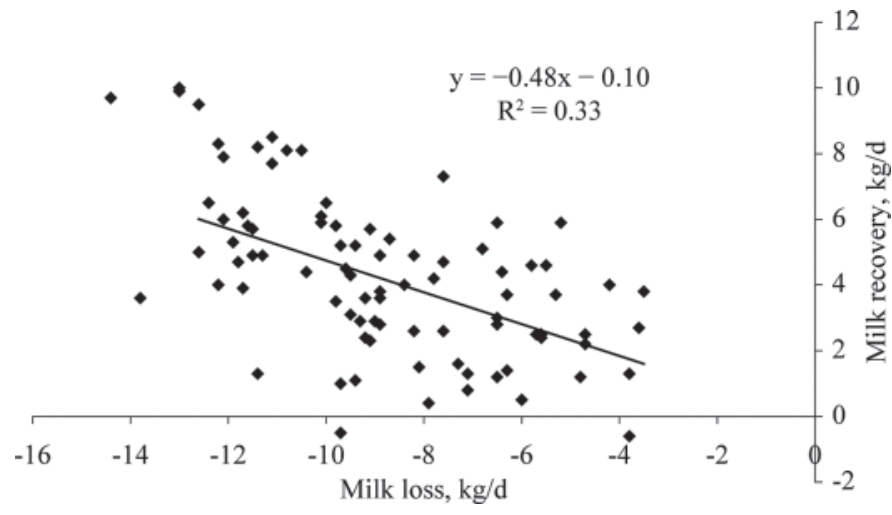

Figure 1. Individual milk loss and recovery of Holstein $\times$ Normande cows when switched back to twice-daily milking after a 3-wk switch to once-daily milking.

our knowledge, no classic genetic studies on these abilities exist at the scale of a selected population. However, results from previous experiments suggest that genetics play only a marginal role in tolerance to ODM, gauged by milk yield losses (Davis et al., 1998a,b). A study comparing 11 sets of twin cows failed to show any correlation to milk yield losses (Davis et al., 1998a). Similarly, trials describing breed effects on milk yield losses have failed to show consistent results between studies (Rémond and Pomiès, 2005). Considering milk recovery, no between- or within-breed observation was made. The ability of dairy cows to overcome the depressive effect of ODM when switched back to TDM, remains to be studied.

\section{Time-Course Evolution of Plasma Lactose Concentrations}

Lactose has been reported as a good indicator of tight junction leakiness (Stelwagen et al., 1997) and a valuable tool for studying mammary permeability in vivo. As milk accumulation in the udder is known to transiently open mammary tight junctions, we hypothesized that variations in lactose concentrations and milk responses would be correlated when cows were switched from TDM to ODM and back to TDM. To estimate the effect of milk accumulation in the udder, lactose concentrations were measured $1 \mathrm{~h}$ before milking (when the udder is full of milk) and 5 to $6 \mathrm{~h}$ after milking to determine baseline lactose (Delamaire and Guinard-Flament, 2005).

Lactose concentrations measured before milking were always significantly higher than the basal levels throughout the experiment (Figure 2). Considering data measured before milking, averaged plasma lactose concentrations rose sharply from 21 to $183 \mathrm{mg} / \mathrm{L}$ following the switch from TDM to ODM (d 1), and then decreased to $41 \mathrm{mg} / \mathrm{L}$ on d 3 and remained unchanged until the last day of ODM (d 21) before decreasing back down to control levels when the cows were switched back to TDM. The lactose baseline increased on $\mathrm{d} 1$ but by d 3 and through to d 28, was no longer different.

Previous studies on dairy cows have reported similar variations in lactose concentrations (Stelwagen et al., 1997, 1998). Plasma lactose concentrations showed rapid elevation beginning 17 to $18 \mathrm{~h}$ after milking on $\mathrm{d}$ 1 of ODM (Stelwagen et al., 1997). On the next day (d 2), lactose levels decreased after milking and increased again, but to a lesser extent, compared with $\mathrm{d} 1$ as milk accumulated in the udder. According to Stelwagen et al. (1997), basal plasma lactose levels are observed within 6 to $8 \mathrm{~h}$ after subsequent milking, and they hypothesize that this results from clearance of lactose from the body and closure of the mammary epithelial tight junctions. The lowest increase in blood plasma observed after $17 \mathrm{~h}$ of milk accumulation on $\mathrm{d} 3$ could result from the lower milk secretion rate observed in

Table 4. Pearson correlations between milk yields during the twice-daily-milking control period (TDM1), the once-daily-milking period (ODM), and the back-to-twice-daily-milking period (TDM2), and milk losses or recoveries expressed as absolute or relative variations, in Holstein $\times$ Normande cows $(n=86)$

\begin{tabular}{|c|c|c|c|c|c|c|}
\hline Item & $\begin{array}{c}\text { TDM1, } \\
\mathrm{kg} / \mathrm{d}\end{array}$ & $\begin{array}{l}\text { ODM, } \\
\mathrm{kg} / \mathrm{d}\end{array}$ & $\begin{array}{c}\text { TDM2, } \\
\mathrm{kg} / \mathrm{d}\end{array}$ & $\begin{array}{l}\mathrm{Loss}^{1}{ }^{1} \\
\mathrm{~kg} / \mathrm{d}\end{array}$ & $\begin{array}{c}\text { Loss, }^{2} \\
\%\end{array}$ & $\begin{array}{c}\text { Recovery, }^{3} \\
\mathrm{~kg} / \mathrm{d}\end{array}$ \\
\hline \multicolumn{7}{|l|}{ Milk yield } \\
\hline ODM, kg/d & $0.83^{* * *}$ & & & & & \\
\hline TDM $2, \mathrm{~kg} / \mathrm{d}$ & $0.87^{* * *}$ & $0.83^{* * *}$ & & & & \\
\hline Loss, ${ }^{1} \mathrm{~kg} / \mathrm{d}$ & $-0.66^{* * *}$ & NS & $-0.44^{* * *}$ & & & \\
\hline Loss, ${ }^{2} \%$ & $-0.22^{*}$ & $0.35^{* *}$ & NS & $0.87^{* * *}$ & & \\
\hline Recovery, ${ }^{3} \mathrm{~kg} / \mathrm{d}$ & $0.34^{* *}$ & NS & $0.56^{* * *}$ & $-0.59^{* * *}$ & $-0.52^{* * *}$ & \\
\hline Recovery rate $^{4}$ & NS & NS & $0.32^{* *}$ & NS & NS & $0.75^{* * *}$ \\
\hline
\end{tabular}

${ }^{1}$ Difference between ODM and TDM1 milk yields.

${ }^{2}$ Difference between ODM and TDM1 milk yields divided by TDM1 milk yield $(\times 100)$.

${ }^{3}$ Difference between TDM2 and ODM milk yields.

*** Significantly different from zero at $P<0.001 ;{ }^{* *}$ significantly different from zero at $P<0.01$; ${ }^{*}$ significantly different from zero at $P<0.05$. 


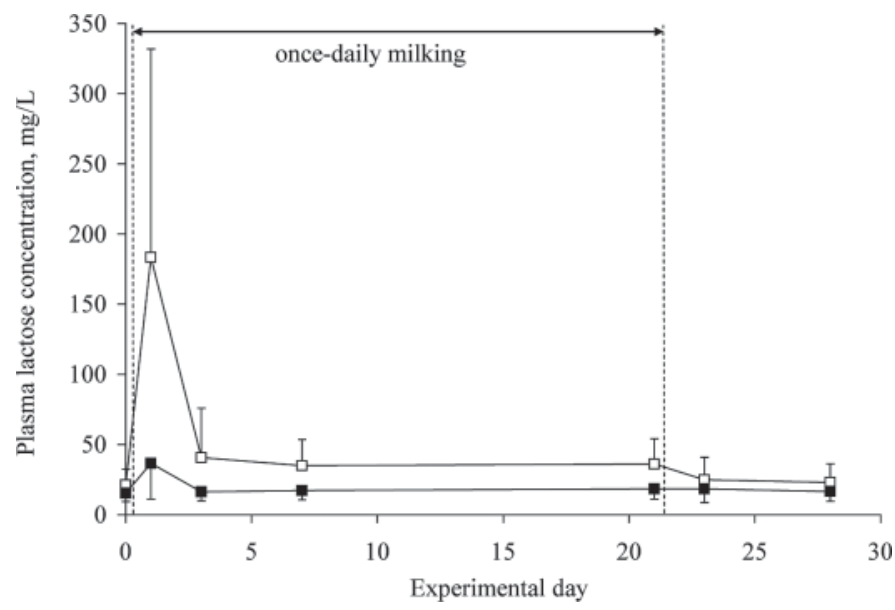

Figure 2. Time-course evolution of blood plasma lactose concentrations throughout the trial ( $\mathrm{d}$ 0: twice-daily-milking control period; d 1, 3, 7, and 21: once-daily-milking period; d 23 and 28: back-totwice-daily-milking period). Symbols represent blood plasma lactose concentrations 1 to $1.5 \mathrm{~h}$ before the morning milking $(\square)$ and 5 to $6 \mathrm{~h}$ after the morning milking (ם).

response to the omission of one daily milking. Indeed, the udder is reportedly sensitive to intra-mammary milk accumulation, demonstrating lower milk secretion rates in the following milking interval (Farr et al., 1998; Pomiès and Rémond, 2000). This lower milk secretion rate would prevent the opening of tight junctions and the sharp increase in lactose concentrations.

\section{Plasma Lactose Concentrations Are Poorly Correlated with Milk Loss}

This study found no specific correlations using within- and between-day differences in plasma lactose. Consequently, only lactose concentrations levels before and after milking are discussed here. Plasma lactose concentrations were not correlated with the level of milk production in the control period or under ODM (except d 1) and TDM2 periods (Table 5). In contrast, plasma lactose concentrations were related to the milk yield variations induced by switching milking frequency.

Milk yield losses (expressed either as $\mathrm{kg} / \mathrm{d}$ or \%) were poorly and inconsistently correlated with plasma lactose concentrations. Absolute values for correlation coefficients ranged from 0.21 to 0.30 (Table 5). These correlations were observed on $\mathrm{d} 1$ but also from $\mathrm{d} 7$ to 28, and differed between days: the higher the lactose concentration before milking on $\mathrm{d} 1$, the lower the milk losses $(\% ; r=0.21)$. In contrast, from $d 7$, the higher the lactose concentration before milking, the higher the milk losses (\%; $\mathrm{r}=-0.30$ on $\mathrm{d} 21)$. These converse results could originate from different mechanisms. The udder's distension capacity could be involved on $\mathrm{d} 1$ : a greater capacity of the udder to distend and accumulate milk on d 1 would result in leakier tight junctions, higher lactose concentrations, and lower milk losses. From d 7, lactose concentration could reflect the resto-

Table 5. Pearson correlations between blood plasma lactose concentrations and milk yield (MY) according to milking frequency of Holstein $\times$ Normande cows ${ }^{1}$

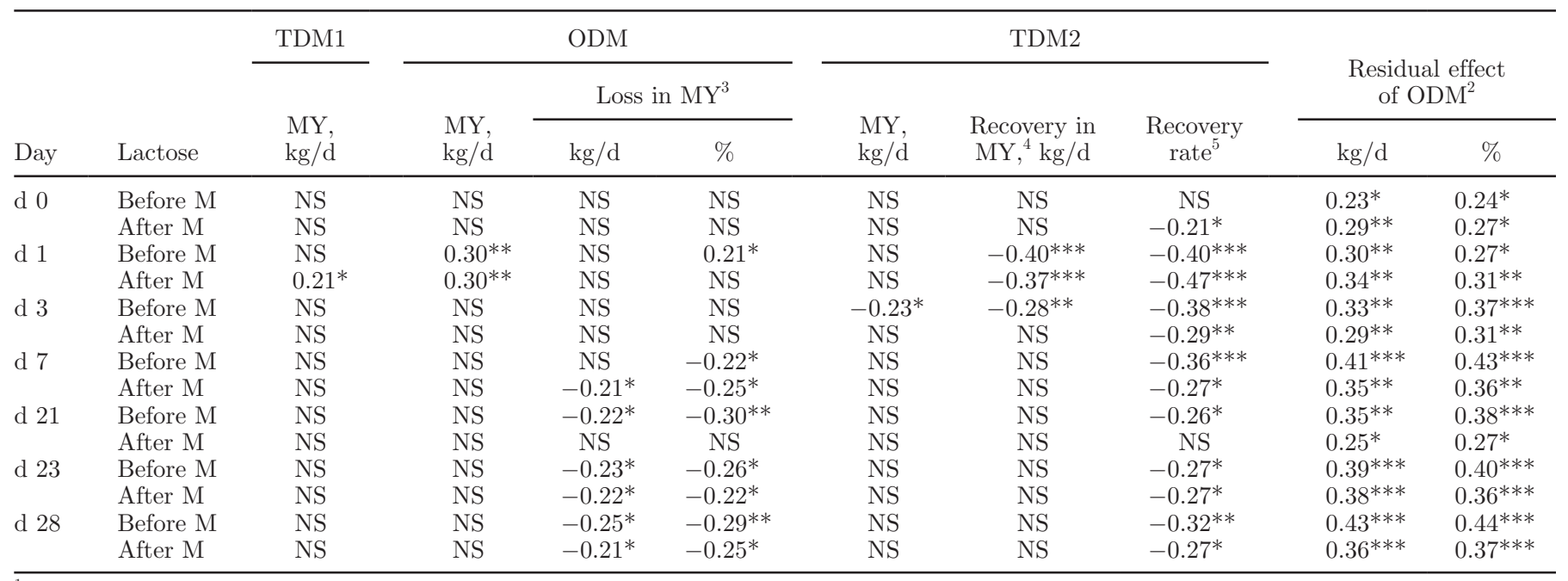

${ }^{1}$ Lactose concentrations were measured at d 0 (twice-daily-milking control period; TDM1); d 1, 3, 7, and 21 (once-daily-milking period; ODM); and $\mathrm{d} 23$ and 28 (back-to-twice-daily-milking period; TDM2) before and after the morning milking (M).

${ }^{2}$ Difference between TDM1 and TDM2 milk yields divided or not by TDM1 milk yield (respectively, \% or kg/d).

${ }^{3}$ Difference between ODM and TDM1 milk yields divided or not by TDM1 milk yield (respectively, \% or kg/d).

${ }^{4}$ Difference between TDM2 and ODM milk yields.

${ }^{5}$ Absolute value of the ratio between milk recovery $(\mathrm{kg} / \mathrm{d})$ and milk loss $(\mathrm{kg} / \mathrm{d})$.

***Significantly different from zero at $P<0.001$; **significantly different from zero at $P<0.01$; ${ }^{*}$ significantly different from zero at $P<0.05$. 
ration of mammary epithelium patency and integrity. Animals demonstrating the highest milk losses under ODM would have incomplete restoration of the mammary epithelium patency, and consequently, higher lactose concentrations.

Previous attempts to identify predictive factors of cow tolerance to ODM were based on hormonal injection to estimate either residual milk or cisternal- and alveolar-compartment milk in the udder (Carruthers et al., 1993; Davis et al., 1998a). It was shown that milk yield losses are lower in cows that store a larger proportion of their total milk production in the cistern (Knight and Dewhurst, 1994; Stelwagen and Knight, 1997; Davis et al., 1998a), and that this storage capacity could be used to predict milk loss. Here, we adopted a different strategy to characterize the ability of individual cows to tolerate ODM by using an easy-to-sample indicator - blood plasma lactose - to indirectly assess udder characteristics and response to ODM. Plasma lactose concentrations were related to milk losses, but only weakly, which suggests no close link between lactose concentrations and milk yield regulation. However, it is possible that the blood sampling procedure here was not suitable enough to establish this relationship. Blood samples were taken $1 \mathrm{~h}$ before milking or 5 to $6 \mathrm{~h}$ after milking, as it was assumed that increases in lactose concentrations could reflect filling of the mammary alveolar compartment and be proportional to the milk production response. However, the point at which plasma lactose concentrations increase could be more useful. By indicating when the milk compartment approaches full capacity, forcing the mammary epithelial barrier open, it could indicate the timing of changes in the milk secretion rate and the milk production response. However, this type of measurement would be more difficult to implement in commercial farms.

As increases in plasma lactose concentration were shown to be closely related to the decrease in milk secretion rate observed over the first $24 \mathrm{~h}$ of intramammary milk accumulation (Stelwagen et al., 1997, 1998), several studies, mostly on dairy goats, have examined the effect of ODM on mammary cell numbers and secretory activity to explain the decrease in milk production and examined the potential role of loosening in the mammary epithelium. These studies converge on a rapid effect of ODM on the mammary epithelial cell activity. After 2 to $7 \mathrm{~d}$ of treatments, decreases in $\alpha$-lactalbumin, and $\beta$ - and $\kappa$-casein mRNA levels have been reported (goat: Yang et al., 2005; cow: Boutinaud et al., 2008; Littlejohn et al., 2010). Once-daily milking also initiates cell death after 6 to $7 \mathrm{~d}$ by activating the transcription of genes involved in the regulation of cell death (Boutinaud et al., 2008; Littlejohn et al., 2010). Likewise, it was shown that ODM compared with milk- ing 3 times daily, induced mammary epithelial cell death by apoptosis after 4 wk ( $\mathrm{Li}$ et al., 1999; BernierDodier et al., 2010) and decreased cell numbers per alveolus and alveolar diameter (Boutinaud et al., 2003). Stelwagen et al. (1997) hypothesized that the switch of tight junctions to a leaky state during the first $24 \mathrm{~h}$ of ODM may be part of the acute regulatory mechanism decreasing milk yield. This assumption is consistent with data from oligonucleotide-array study (Littlejohn et al., 2010) or from studies using calcium chelators to mimic the effect on mammary epithelium integrity (Stelwagen et al., 1995; Ben Chedly et al., 2010). These studies reported decreased synthetic activity and the induction of cell death. Both regulatory mechanisms could explain the decrease in milk yield caused by the switch from TDM to ODM. Likewise, it can be hypothesized that both mechanisms, especially cell death by apoptosis, could be involved in the incomplete milk recovery when cows are switched back to TDM.

\section{Plasma Lactose Concentrations Are Correlated with Milk Recovery}

Milk recovery rates and residual effects of ODM (expressed in $\mathrm{kg} / \mathrm{d}$ or \%) were always correlated with plasma lactose except before milking in the control period and after milking at d 21 for milk recovery rates. Correlation coefficients were low in the control period $(|r| \leq 0.29)$ but higher on the subsequent days, where they ranged from $|0.25|$ to $|0.47|$. Correlation coefficients between lactose concentration and milk recovery rates and residual effects varied in the same range (from $|0.21|$ to $|0.47|$ and from $|0.23|$ to $|0.44|$, respectively) and were higher than those previously reported for milk losses. There was good agreement between correlations of milk recovery rates and of residual effects: the higher the plasma lactose concentration, the lower the milk recovery rate, and the higher the residual effect. Our findings, thus, suggest that an increased permeability of the mammary epithelium before and during ODM resulted in a lower milk recovery and a larger residual effect when switching back from ODM to TDM.

These results highlight the relationship between plasma lactose concentration and milk recovery when cows are switched back to TDM. To our knowledge, this correlation has never previously been reported. It suggests that the integrity state of the mammary epithelium is a factor that modulates milk recovery and determines the residual effects of ODM on milk yield. This effect could be mediated by irreversible ODM-induced mammary cell death. Indeed, the decrease in the mammary cell numbers without compensatory cell proliferation could limit the increase in milk yield when cows are switched back to TDM. 
Residual effects were always correlated with plasma lactose concentration, even in the control period, partly because lactose concentrations are intercorrelated: cows with high lactose concentrations in the control period also had high lactose concentrations on the other days of the experiment $(\mathrm{r}=0.60$ between $\mathrm{d} 0$ and 28 for data before milking; $P<0.0001)$. This consistency could suggest animal-scale determinism of loosening of mammary epithelium, with cows having more or less leaky mammary epithelial cells. This animal determinism may be genetics dependent and the issue of genetic determinism underlying the ability of cows to respond with only minor residual effects of ODM when switched back to TDM warrants further investigation.

Our study data does contain high variability and it should be pointed out that 1 group of 11 cows exhibited exacerbated blood lactose concentration responses, leading to markedly depressed milk recovery rates. These cows showed a sharp rise in blood lactose concentration before milking on d 1, with lactose concentrations peaking at over $350 \mathrm{mg} / \mathrm{L}$. These cows had similar milk losses but demonstrated a lesser ability to recover milk yield $(-2 \mathrm{~kg} / \mathrm{d})$ than did the other cows (Figure 3). This acute response was observed after 3 wk of ODM, and could result from a sharp decrease in mammary cell numbers. This is a point that warrants investigation and it remains to be determined whether the same response pattern would be observed when omitting only a single milking.

\section{CONCLUSIONS}

Once-daily milking is potentially useful to dairy farms, as it can decrease workload over a short or long period or even a whole lactation cycle. However, to viably implement ODM, the cows have to be ODM tolerant, showing both low milk yield loss and low residual effects when switched back to TDM, and no negative effects on udder health. Milk loss (\%) and rate of milk recovery are viable descriptors of a cow's ability to handle the negative effects of ODM on milk yield. Our study shows that these criteria are independent, meaning that to be selected for ODM, a cow has to be well adapted to milk loss and well adapted to milk recovery. The study aimed to determine whether plasma lactose concentration measured before and during ODM is a good candidate assessor of ability of cows to tolerate ODM. We found that plasma lactose concentration failed to estimate the aptitude of cows to present only minor milk losses in response to the switch to ODM. In fact, lactose concentration proved more useful for evaluating the aptitude of cows to show limited residual effects on milk when switched from ODM back to TDM. However, for this purpose, it would need to be

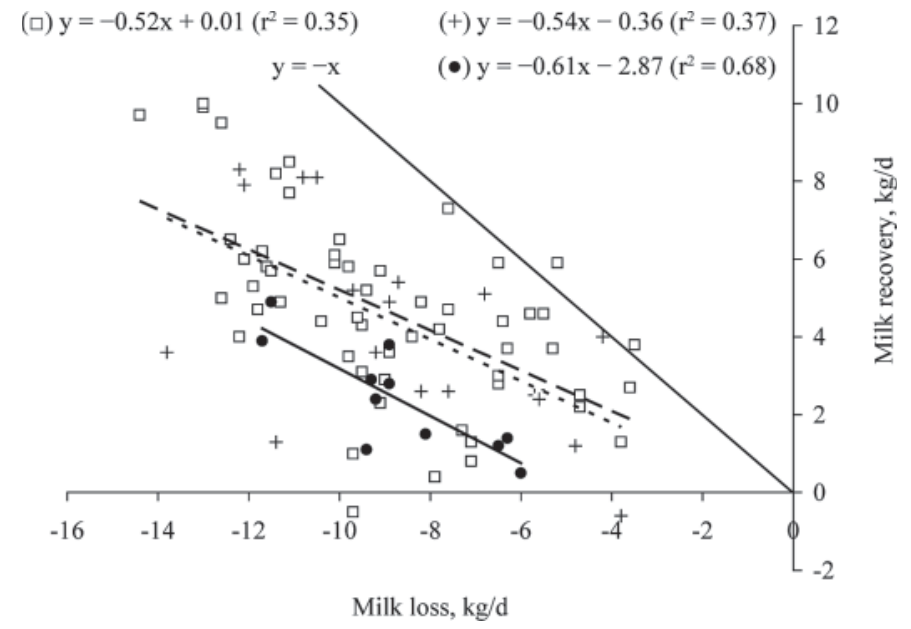

Figure 3. Milk yield recovery according to milk yield loss of Holstein $\times$ Normande cows switched from twice-daily milking to oncedaily milking (milk loss) and then back to twice-daily milking (milk recovery). Symbols represent cows that, on the first day of once-daily milking before the morning milking, presented blood plasma lactose concentration $\leq 200 \mathrm{mg} / \mathrm{L}(\square ; \mathrm{n}=57) ; 200 \mathrm{mg} / \mathrm{L}<$ lactose concentration $\leq 350 \mathrm{mg} / \mathrm{L}(+; \mathrm{n}=18) ;$ and $>350 \mathrm{mg} / \mathrm{L}(\bullet ; \mathrm{n}=11)$.

coupled with other indicators to improve the precision of the prediction.

\section{ACKNOWLEDGMENTS}

The authors thank the staff at the INRA Domaine expérimental du Pin experimental farm for help with animal care and handling. We also thank Sylvie Marion and Thibaud Le Mouel (INRA, St-Gilles, France) for technical assistance, Emilie Kermeur and Pierre-Jean Bouyge (INRA, Pin-au-Haras, France) for data reduction, Luc Delaby (INRA, St-Gilles, France) and Christèle Robert-Granié (INRA, Castanet-Tolosan, France) for helpful discussions and A-T-T scientific editing services (Clermont-Ferrand, France) for proofreading the manuscript.

\section{REFERENCES}

Ben Chedly, H., M. Boutinaud, P. Bernier-Dodier, P.-G. Marnet, and P. Lacasse. 2010. Disruption of cell junctions induces apoptosis and reduces synthetic activity in lactating goat mammary gland. J. Dairy Sci. 93:2938-2951.

Bernier-Dodier, P., L. Delbecchi, G. F. Wagner, B. G. Talbot, and P. Lacasse. 2010. Effect of milking frequency on lactation persistency and mammary gland remodeling in mid-lactation cows. J. Dairy Sci. 93:555-564.

Boutinaud, M., M. H. Ben Chedly, E. Delamaire, and J. GuinardFlament. 2008. Milking and feed restriction regulate transcripts of mammary epithelial cells purified from milk. J. Dairy Sci. 91:988-998.

Boutinaud, M., C. Rousseau, D. H. Keisler, and H. Jammes. 2003. Growth hormone and milking frequency act differently on goat mammary gland in late lactation. J. Dairy Sci. 86:509-520.

Carruthers, V. R., S. R. Davis, A. M. Bryant, H. V. Henderson, C. A. Morris, and P. J. A. Copeman. 1993. Response of Jersey and 
Friesian cows to once a day milking and prediction of response based on udder characteristics and milk composition. J. Dairy Res. 60:1-11.

Davis, S. R. 2005. Lactational traits of importance in dairy cows and applications for emerging biotechnologies. N. Z. Vet. J. 53:400405 .

Davis, S. R., V. C. Farr, P. J. Copeman, V. R. Carruthers, C. H. Knight, and K. Stelwagen. 1998a. Partitioning of milk accumulation between cisternal and alveolar compartments of the bovine udder: Relationship to production loss during once daily milking. J. Dairy Res. 65:1-8.

Davis, S. R., V. C. Farr, and K. Stelwagen. 1998b. Once-daily milking of dairy cows: An appraisal. Proc. N.Z. Soc. Anim. Prod. $58: 36-40$

Davis, S. R., V. C. Farr, and K. Stelwagen. 1999. Regulation of yield loss and milk composition during once-daily milking: A review. Livest. Prod. Sci. 59:77-94.

Delamaire, E., and J. Guinard-Flament. 2005. Milking frequency affects mammary epithelium integrity from 16-h milking interval in dairy cows. Livest. Prod. Sci. 98:178 (Abstr.)

Delamaire, E., and J. Guinard-Flament. 2006. Longer milking intervals alter mammary epithelial permeability and the udder's ability to extract nutrients. J. Dairy Sci. 89:2007-2016.

Farr, V. C., K. Stelwagen, and A. J. Davis. 1998. Rates of recovery of milk yield and composition following milking intervals of varying length. Proc. N.Z. Soc. Anim. Prod. 58:47-48.

Hickson, R. E., N. Lopez-Villalobos, D. E. Dalley, D. A. Clark, and C W. Holmes. 2006. Yields and persistency of lactation in Friesian and Jersey cows milked once daily. J. Dairy Sci. 89:2017-2024.

Holmes, C. W., G. F. Wilson, D. D. S. Mackenzie, and J. Purchas. 1992. The effects of milking once daily throughout lactation on the performance of dairy cows grazing on pasture. Proc. N.Z. Soc. Anim. Prod. 52:13-16.

Institut National de la Recherche Agronomique. 1989. Feeding standards for ruminants. Pages 15-22 in Ruminant Nutrition. Recommended Allowances and Feed Table. J. Libbey, ed. Eurotext, London, UK.

Knight, C. H., and R. J. Dewhurst. 1994. Once daily milking of dairy cows: Relationship between yield loss and cisternal milk storage. J. Dairy Res. 61:441-449.

Kuhn, N. J., and J. L. Linzell. 1970. Measurement of the quantity of lactose passing into mammary venous plasma and lymph in goats and in a cow. J. Dairy Res. 37:203-208.
Larroque, H., Y. Gallard, L. Thaunat, D. Boichard, and J. J. Colleau. 2002. A crossbreeding experiment to detect quantitative trait loci in dairy cattle. Page 219-222 in Proc. 7th World Congress on Genetics Applied to Livestock Production, Montpellier, France. INRA-Centre de coopération internationale en recherche agronomique pour le développement (CIRAD), Versailles, France.

Li, P., P. S. Rudland, D. G. Fernig, L. M. Finch, and C. J. Wilde. 1999. Modulation of mammary development and programmed cell death by the frequency of milk removal in lactating goats. J. Physiol. 519:885-900.

Littlejohn, M. D.. C. G. Walker, H. E. Ward, K. B. Lehnert, R. G. Snell, G. A. Verkerk, R. J. Spelman, D. A. Clark, and S. R. Davis. 2010. Effects of reduced frequency of milk removal on gene expression in the bovine mammary gland. Physiol. Genomics 41:21-32.

Pomiès, D., and B. Rémond. 2000. Omission de une ou deux traites par semaine sur des vaches laitières en milieu de lactation. Page 128 in 7ème Rencontres autour des Recherches sur les Ruminants, Paris, France. Institut de l'Elevage-INRA, Paris, France. (Abstr.)

Rémond, B., and D. Pomiès. 2005. Once-daily milking of dairy cows: A review of recent French experiments. Anim. Res. 54:427-442.

Stelwagen, K., S. R. Davis, V. C. Farr, S. J. Eichler, and I. Politis. 1994. Effect of once daily milking and concurrent somatotropin on mammary tight junction permeability and yield of cows. J. Dairy Sci. 77:2994-3001.

Stelwagen, K., V. C. Farr, S. R. Davis, and C. G. Prosser. 1995. EGTA-induced disruption of epithelial cell tight junctions in the lactating caprine mammary gland. Am. J. Physiol. 269:R848-R855.

Stelwagen, K., V. C. Farr, H. A. McFadden, C. G. Prosser, and S. R. Davis. 1997. Time course of milk accumulation-induced opening of mammary tight junctions, and blood clearance of milk components. Am. J. Physiol. 273:R379-R386.

Stelwagen, K., and C. H. Knight. 1997. Effect of unilateral once or twice daily milking of cows on milk yield and udder characteristics in early and late lactation. J. Dairy Res. 64:487-494.

Stelwagen, K., D. C. van Espen, G. A. Verkerk, H. A. McFadden, and V. C. Farr. 1998. Elevated plasma cortisol reduces permeability of mammary tight junctions in the lactating bovine mammary epithelium. J. Endocrinol. 159:173-178.

Yang, J., B. Zhao, V. E. Baracos, and J. J. Kennelly. 2005. Effects of bovine somatotropin on beta-casein mRNA levels in mammary tissue of lactating cows. J. Dairy Sci. 88:2806-2812. 